\title{
Birt-Hogg-Dubé Syndrome: Answering Questions Raised by a Case Report Published in 1962
}

\author{
Pashtoon Murtaza Kasi ${ }^{\mathrm{a}}$ Daniel T. DeArmond ${ }^{\mathrm{b}}$ \\ anternational Scholars Program, Department of Medicine, University of \\ Pittsburgh Medical Center, Pittsburgh, Pa., and bepartment of Cardiothoracic \\ Surgery, University of Texas Health Science Center at San Antonio, \\ San Antonio, Tex., USA
}

\section{Key Words}

Birt-Hogg-Dubé syndrome - Spontaneous pneumothorax - Renal cell carcinoma - Cancer . Melanoma Folliculin gene $\cdot$ Tumor supressor gene

\begin{abstract}
In 1962, J.J. Collins from the United States Naval Medical Research Laboratory published an unusual case of air embolism precipitated by decompression in The New England Journal of Medicine [1962;266:595-598]. The case was unusual because it was the first where multiple pulmonary cysts were discovered after a successful recompression treatment. Although various hypotheses were put forward by the author, it was thought that the diver might have had 'subclinical cysts' already present because of some disease phenomenon, which then became overinflated during decompression. Nearly 50 years have passed since these questions were raised. Interestingly, now the disease process is trying to unveil itself through various other clues. We present the case of the same diver who later developed a series of other medical problems, along with more than 5 admissions for spontaneous pneumothoraces, all falling into the constellation represented by the Birt-Hogg-Dubé syndrome. Birt-Hogg-Dubé syndrome is an autosomal dominant condition clinically characterized by skin fibrofolliculomas, pulmonary cysts, spontaneous pneumothorax, and renal cancer. It was first described in 1977 by Birt, Hogg and Dubé in a family with 'hereditary multiple fibrofolliculomas with trichodiscomas and acrochordons'. Spontaneous pneumothorax can be the first manifestation of this hereditary condition, and prevention in patients diagnosed with the syndrome is aimed at early diagnosis and treatment of the renal cell carcinoma. Physicians need to have a high index of suspicion when they see patients with the constellation of findings of this underdiagnosed syndrome, especially in patients with unexplained spontaneous pneumothoraces.
\end{abstract}




\section{Reviewed Case Report}

In 1962, J.J. Collins from the United States Naval Medical Research Laboratory published an unusual case of air embolism precipitated by decompression in The New England Journal of Medicine [1]. The case was unusual because it was the first where multiple pulmonary cysts were discovered after a successful recompression treatment. $\mathrm{X}$-ray films taken $1 \mathrm{~h}$ after the treatment showed several cystic areas in the left upper lobe, some of which had air-fluid levels.

Although various hypotheses were put forward by the author, it was thought that the diver might have had 'subclinical cysts' already present because of some disease phenomenon, which then became overinflated during decompression.

Nearly 50 years have passed since these questions were raised. Interestingly, now the disease process is trying to unveil itself through various other clues.

The same diver later developed a series of other medical problems (table 1), which were diagnosed and treated one after the other until recently, when an intern tried to look for a possible explanation/syndrome for the patient's bullous emphysematous disease (fig. 1) since the diver was admitted more than 5 times for repeated spontaneous pneumothoraces. The intern found out that all the patient's medical problems are typical characteristics of the Birt-Hogg-Dubé (BHD) syndrome.

BHD syndrome is an autosomal dominant condition clinically characterized by skin fibrofolliculomas, pulmonary cysts, spontaneous pneumothorax, and renal cancer [2]. It was first described in 1977 by Birt, Hogg and Dubé in a family with 'hereditary multiple fibrofolliculomas with trichodiscomas and acrochordons' [3]. The genetic defect appears to be in the folliculin gene mapped to chromosome 17p12q11, which appears to be a tumor suppressor gene [4].

Spontaneous pneumothorax can be the first manifestation of this hereditary condition, and prevention in patients diagnosed with the syndrome is aimed at early diagnosis and treatment of the renal cell carcinoma (RCC). Our patient already had had curative resection of a clear cell-type RCC a decade ago - the most commonly seen subtype in BHD syndrome. The patient actually had tumors on both sides and is currently already being followed by a urologist. The patient's pneumothoraces required multiple admissions as well as multiple tube thoracostomies and, finally, a stapled bleb resection was performed, after which the patient has been doing well.

\section{Conclusion}

Herein, it is important to realize that in individuals affected or at risk of BHD syndrome, the clinical expression varies greatly, and that patients may not exhibit any skin manifestations at all. However, they are predisposed to multiple renal tumors (more than $27 \%$ in a series from Maryland, USA [5]) and need constant surveillance including colonoscopy since some patients are at high risk for colorectal cancers. Physicians need to have a high index of suspicion when they see patients with the constellation of findings of this underdiagnosed syndrome. 


\section{Acknowledgements}

We are deeply indebted to the patient for allowing us to present his information as a case report. Thanks are also due to the Department of Surgery and Dr. Daniel Dent for his constant support and encouragement.

\section{Disclosure Statement}

The authors declare that they do not have any conflicts of interest.

Table 1. Observations seen in various case series on BHD syndrome [1-3] as well as in our patient

\begin{tabular}{|c|c|c|}
\hline Tumor site & Observations in BHD syndrome & Observations in our patient \\
\hline Skin & $\begin{array}{l}\text { Fibrofolliculomas, trichodiscomas, and } \\
\text { acrochordons on the face, neck, and upper } \\
\text { torso }\end{array}$ & $\begin{array}{l}\text { Our patient has had multiple dermatological } \\
\text { visits, with removal of acrochordons several } \\
\text { times. }\end{array}$ \\
\hline Skin & Melanoma & Yes \\
\hline Skin & Lipoma & Yes \\
\hline Skin & Squamous cell carcinoma & $\begin{array}{l}\text { Yes; along with multiple biopsies of } \\
\text { suspicious lesions which showed actinic } \\
\text { keratosis. }\end{array}$ \\
\hline Lung & $\begin{array}{l}\text { Pulmonary air-filled cysts/bullous } \\
\text { emphysematous changes }\end{array}$ & $\begin{array}{l}\text { Yes; bullous emphysematous changes are } \\
\text { noted in the left upper lobe in our patient, } \\
\text { leading to repeated spontaneous } \\
\text { pneumothoraces (fig. 1). }\end{array}$ \\
\hline Lung & Spontaneous pneumothorax & $\begin{array}{l}\text { Yes; our patient has had repeated } \\
\text { admissions for pneumothoraces with } \\
\text { persistent air leaks most likely due to } \\
\text { rupture of various blebs. }\end{array}$ \\
\hline Kidney & Renal tumors (clear cell and papillary) & $\begin{array}{l}\text { Yes; renal cell carcinoma (clear-cell type), } \\
\text { including renal bilateral renal cysts. }\end{array}$ \\
\hline Colon & $\begin{array}{l}\text { In the past, an association between BHD } \\
\text { syndrome and colorectal polyps and cancer } \\
\text { was also suggested. However, recent studies } \\
\text { indicate that colorectal tumors are not } \\
\text { associated with the syndrome or, } \\
\text { alternatively, occur only in a small subset } \\
\text { of families. }\end{array}$ & $\begin{array}{l}\text { Yes; our patient had a colorectal adenoma } \\
\text { excised on a colonoscopy. Biopsy showed } \\
\text { tubulovillous adenoma. }\end{array}$ \\
\hline $\begin{array}{l}\text { Other rare } \\
\text { tumors }\end{array}$ & $\begin{array}{l}\text { Other tumors were reported in } 11 \text { clinically } \\
\text { affected BHD patients and/or carriers of } \\
\text { mutations in the folliculin gene: benign } \\
\text { breast disease, oral fibroma, lipomas, } \\
\text { inverted papilloma of the nose, fibrosarcoma } \\
\text { of the leg, skin basal cell carcinoma, human } \\
\text { immunodeficiency virus-related B-cell } \\
\text { non-Hodgkin lymphoma and breast cancer. }\end{array}$ & \\
\hline
\end{tabular}




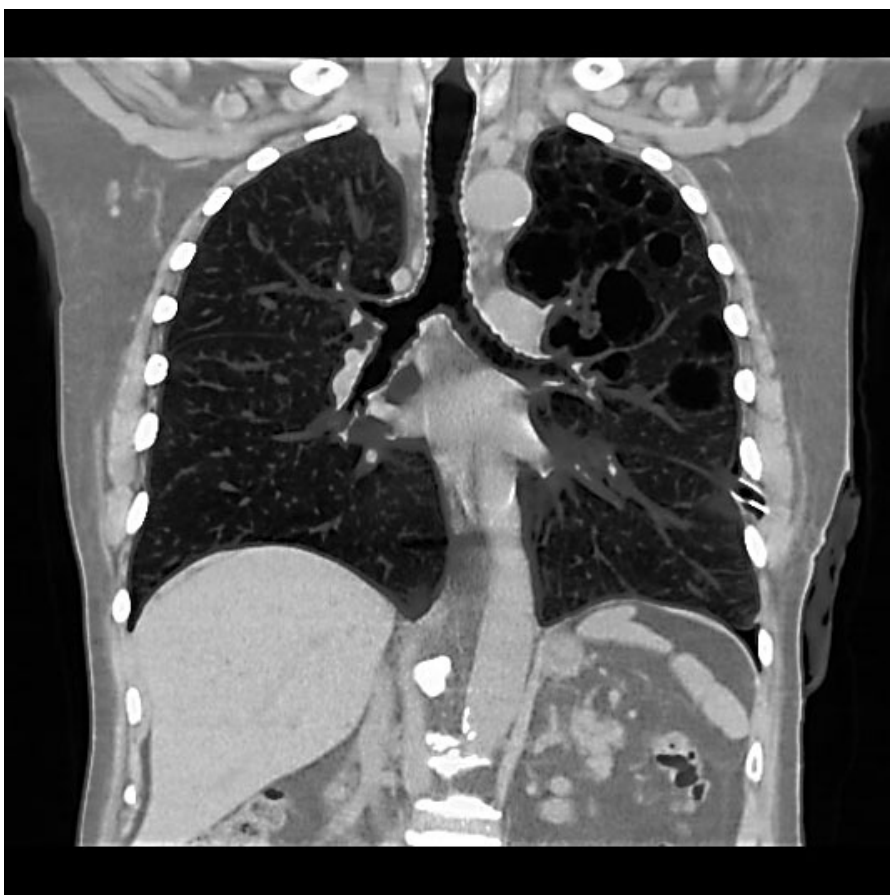

Fig. 1. Bullous emphysematous disease causing spontaneous pneumothoraces, most evident in the left upper lobe in this figure.

\section{References}

1 Collins JJ Jr: An unusual case of air embolism precipitated by decompression. N Engl J Med 1962;266:595-598.

-2 Menko FH, van Steensel MA, Giraud S, Friis-Hansen L, Richard S, Ungari S, Nordenskjöld M, Hansen TV, Solly J, Maher ER: Birt-Hogg-Dubé syndrome: diagnosis and management. Lancet Oncol 2009;10:1199-1206.

-3 Birt AR, Hogg GR, Dubé WJ: Hereditary multiple fibrofolliculomas with trichodiscomas and acrochordons. Arch Dermatol 1977;113:1674-1677.

4 Adley BP, Smith ND, Nayar R, Yang XJ: Birt-Hogg-Dubé syndrome: clinicopathologic findings and genetic alterations. Arch Pathol Lab Med 2006;130:1865-1870.

-5 Pavlovich CP, Grubb RL 3rd, Hurley K, Glenn GM, Toro J, Schmidt LS, Torres-Cabala C, Merino MJ, Zbar B, Choyke P, Walther MM, Linehan WM: Evaluation and management of renal tumors in the Birt-Hogg-Dubé syndrome. J Urol 2005;173:1482-1486. Erratum in: J Urol 2005;174:796. 